\title{
Total Phenolic Content and Tyrosinase Inhibitory Potential of Extracts from Cajanus cajan (L.) Millsp.
}

\author{
Prasob-on Rinthong ${ }^{1}$ and Suthira Maneechai ${ }^{2^{*}}$
}

\section{Suthira Maneechai ${ }^{2, *}$, Prasoborn Rinthong ${ }^{1}$}

${ }^{1}$ Faculty of Pharmacy, Mahasarakham University, Kham Riang, Kantharawichai, Mahasarakham, THAILAND. ${ }^{2}$ Department of Biology, Faculty of Science, Mahasarakham University, THAILAND.

\section{Correspondence}

\section{Dr. Suthira Maneechai}

Department of Biology, Faculty of Science, Mahasarakham University, Kantarawichai Distric. Maha Sarakham 44150, THAILAND.

Phone no : +6643754245

E-mail: suthira.m@msu.ac.th

\section{History}

- Submission Date: 22-06-2018;

- Review completed: 07-08-2018;

- Accepted Date: 18-09-2018

DOI : 10.5530/pj.2018.6s.21

Article Available online http://www.phcogj.com/v10/i6s

\section{Copyright}

(c) 2018 Phcog.Net. This is an openaccess article distributed under the terms of the Creative Commons Attribution 4.0 International license.

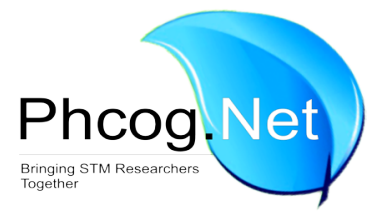

\begin{abstract}
Background: Cajanus cajan (L.) Millsp. (Fabaceae) is a legume plant which used for human food and animal feed. Objective: The present study was aimed to investigate total phenolic content and tyrosinase inhibitory potential of the root, stem and seed parts of C. cajan. Method: Crude extracts were prepared by reflux extraction using methanol, dichloromethane and water as solvents. Total phenolic contents of the obtained extracts were analyzed by FolinCiocalteu colorimetric method and the inhibitory effect on tyrosinase activity was determined spectrophotometrically. Results: The results revealed that dichloromethane seed extract had more total phenolic content than those of methanol and water seed extracts, respectively. Dichloromethane seed extract had the highest total phenolic content of $92.00 \pm 1.24 \mathrm{mg}$ GAE/ g extracts. However, the highest tyrosinase inhibitory activity was found in the root methanol extract with $\mathrm{IC}_{50}$ of $3.55 \pm 0.35 \mathrm{mg} / \mathrm{ml}$. Conclusion: Type of extraction solvent was an important factor on phenolic contents of $C$. cajan extracts. The extracts of $C$. cajan inhibit slightly tyrosinase inhibitory.

Key words: Cajanus cajan, Total phenolic content, Tyrosinase inhibitor, Dichloromethane seed extract, Root methanol extract.
\end{abstract}

\section{INTRODUCTION}

Medicinal plants are used in an alternative medicine for centuries. One of the most interesting medicinal plants is Cajanus cajan (L.) Millsp. (Fabaceae) or pigeon pea. It is an erect, branched, hairy shrub, 1-2 meters high. Leaves are oblong-lanceolate to oblanceolate with three leaflets. Flowers are yellow, in sparse peduncled racemes. Pod is hairy containing two to seven seeds. It is a multipurpose plant as extensively eaten as a dal for Indian people. In Thailand, young shoots of this plant are eaten as vegetables and the mature fruits are steamed for edible seeds. In traditional Chinese medicine, C. cajan is indicated for pain relief and used as a sedative agent. It is also used to treat ischemic necrosis, wound healing, sores, skin irritations, hepatitis, measles, jaundice and stabilizing menstrual period. ${ }^{1}$

Phenolic compounds are the most abundant secondary metabolites in plants. Phytochemical studies revealed that C. cajan contained various types of phenolic compounds including genistein, cajanol, biochanin A, longistylin A and C. ${ }^{2-6}$ Biochanin A has been reported to exhibit tyrosinase inhibition. ${ }^{7}$ The melanogenesis inhibitory effect occurs due to the 20 phenolic compounds determined in the extract from Morus alba. ${ }^{8}$ Phenolics have similar structures to tyrosine which are oxidized by tyrosinase and they can act as substrate analog inhibitors against melanogenesis. ${ }^{9}$ Moreover, tyrosinase is commonly found in living organisms. It activates the color change of mushroom, vegetables and fruits into dark brown. This enzyme is responsible for molting process in insects and regulates melanin synthesis process resulting in color determination of skin, hair and eyes in animals. ${ }^{10}$ Antityrosinase agents usually lower melanin synthesis process. It helps to prevent of melanin accumulation. This advantage has been applied in the whitening cosmetic industries. Currently, medicinal plant derived cosmetics are widely interested. Many research groups are interested in the investigation and screening of effective medicinal plants for developing as whitening agent. C. cajan has been reported various biological activities including anti-microbial, anti-oxidant and anti-cancer. ${ }^{2-6}$ However, there is no report on its tyrosinase inhibitory activity. Therefore, the present study was aimed to determine total phenolic contents and to investigate the tyrosinase inhibitory activity of the root, stem and seed extracts of C. cajan. The findings from this study would be scientific information for value addition of Thai local plants and used as basic data for further application and development of cosmetic and food supplementary product industries.

\section{MATERIALS AND METHODS}

\section{Chemicals}

Folin-Ciocalteu (Sigma-Aldrich), sodium carbonate $\left(\mathrm{Na}_{2} \mathrm{CO}_{3}\right)$, DMSO (Sigma-Aldrich), Kojic acid 
(Sigma-Aldrich), L-DOPA (Sigma-Aldrich), Mushroom tyrosinase enzyme (Sigma-Aldrich), Gallic acid (Sigma-Aldrich), phosphate buffer, dichloromethane AR grade (Merck) and methanol AR grade (Merck).

\section{Plant materials and extract preparation}

The root, stem and seed parts of $C$. cajan were collected from the cultivation area in Sila sub-district, Muang district, Khon Kean province, Northeastern part of Thailand. The plant specimens were identified using keys to genus and species and compared to type specimens. The voucher specimens were deposited in Bangkok herbarium, Bangkok, Thailand. The plant parts were dried in hot air oven at $60^{\circ} \mathrm{C}$ until dry. Then, they were homogenized as the fine powders. $10 \mathrm{~g}$ of plant powder (root, stem and seed) was dissolved in $300 \mathrm{ml}$ of different solvents including methanol, dichloromethane and water. The plant extracts were prepared by reflux extraction at $60^{\circ} \mathrm{C}$ for $30 \mathrm{~min}$. The solutions were evaporated by water bath at $60^{\circ} \mathrm{C}$ and freeze dried as crude extracts. The extracts were kept in freezer at $-20^{\circ} \mathrm{C}$ until use.

\section{Determination of total phenolic contents}

Total phenolic contents in the plant extracts were analyzed by FolinCiocalteu colorimetric method modified from Amin et al. ${ }^{8}$ Gallic acid at the concentrations of $12.5,25,50,80$ and $100 \mathrm{mg} / \mathrm{ml}$ was used as a standard. The plant extracts were dissolved in methanol. $0.5 \mathrm{ml}$ of extracts (at the concentration of $1 \mathrm{mg} / \mathrm{ml}$ ) was mixed with $2.5 \mathrm{ml}$ FolinCiocalteu solution and left at room temperature for $5 \mathrm{~min}$. Then, $2 \mathrm{ml}$ $\mathrm{Na}_{2} \mathrm{CO}_{3}$ solution was added to the solution. The solution was mixed well and adjusted volume into $5 \mathrm{ml}$ by distilled water and left at room temperature for $2 \mathrm{~h}$. The solutions were measured for the absorbance at wavelength of $760 \mathrm{~nm}$. Finally, total phenolic contents of extracts were calculated by comparison to gallic acid's standard curve (mg of gallic acid equivalent (GAE)/g extract)

\section{Tyrosinase inhibitory activity study}

Tyrosinase inhibitory activity study was carried out by the methods modified from Alam et al..$^{9}$ Tyrosinase enzyme was extracted from mushroom. The plant extracts were dissolved in 50\% DMSO at the concentration of $5 \mathrm{mg} / \mathrm{ml}$. $40 \mu \mathrm{l}$ extracts were mixed with $80 \mu \mathrm{l}$ sodium phosphate buffer $(0.1 \mathrm{M}, \mathrm{pH} 6.8)$ and $40 \mu \mathrm{l}$ of 31 units/ml tyrosinase enzyme (dissolved in sodium phosphate buffer). The solutions were added to the microplate (mixed well) and incubated at room temperature for $10 \mathrm{~min}$. Then, the solutions were mixed with $40 \mu \mathrm{l}$ of $2.5 \mathrm{mM}$ L-DOPA and left at room temperature for $10 \mathrm{~min}$. The solutions were measured for the absorbance by microplate reader (SPECTRO star Nano, BMG LabTech) at wavelength of $475 \mathrm{~nm}$. Kojic acid was used as a standard. Percentage inhibitions of tyrosinase activity were calculated by using the following equation:

$$
\% \text { Inhibition }=100[(\mathrm{~A}-\mathrm{B})-(\mathrm{C}-\mathrm{D})] /(\mathrm{A}-\mathrm{B})
$$

When $\mathrm{A}=$ absorbance of blank; $\mathrm{B}=$ absorbance of control; $\mathrm{C}=$ absorbance of extracts in the presence of tyrosinase; $\mathrm{D}=$ absorbance of extracts in the absence of tyrosinase

\section{Statistical analysis}

Total phenolic contents and tyrosinase inhibitory activity were carried out in 3 replicates $(n=3)$. The results were expressed as mean \pm S.D.

\section{RESULTS}

Crude extracts of root, stem and seed parts of C. cajan using methanol, dichloromethane and water were prepared by reflux extraction. The methanol and dichloromethane extracts were dried by using rotary evaporator while water extracts were dried by using freeze dryer. The dry weights of crude extracts were used for calculation of percentage yield (\% yield). The results showed that the water extracts from root, stem and seed had the highest percentage yield. However, the methanol seed extracts had the highest percentage yield as shown in Table 1.

\section{Total phenolic contents}

Total phenolic contents of C. cajan extracts were ranged from 4.27 $92.00 \mathrm{mg} \mathrm{GAE} / \mathrm{g}$ extracts. Total phenolic contents of dichloromethane, methanol and water seed extracts are $92.00 \pm 1.24,50.03 \pm 2.78$ and 4.27 $\pm 0.91 \mathrm{mg} \mathrm{GAE} / \mathrm{g}$ extracts, respectively. The dichloromethane, methanol and water root extracts contained the total phenolic contents of $80.28 \pm$ $4.49,41.02 \pm 0.77$ and $5.95 \pm 0.99 \mathrm{mg} \mathrm{GAE} / \mathrm{g}$ extracts, respectively. The stem extracted with dichloromethane, methanol and water has the total phenolic contents of $72.46 \pm 4.09,30.57 \pm 1.33$ and $9.16 \pm 0.69 \mathrm{mg} \mathrm{GAE} / \mathrm{g}$ extracts, respectively (Table 2 ).

\section{Tyrosinase inhibitory activity}

Tyrosinase inhibitory activity of $C$. cajan extracts was expressed as $\mathrm{IC}_{50}$ values. The results revealed that the extracts exhibited tyrosinase inhibitory activity with $\mathrm{IC}_{50}$ values ranging from $3.55-12.43 \mathrm{mg} / \mathrm{ml}$. However, the $\mathrm{IC}_{50}$ value of the standard kojic acid was $0.73 \pm 0.0019 \mathrm{mg} / \mathrm{ml}$ as shown in Table 2.

\section{DISCUSSION}

Plants extracts usually contain different classes of phenolic compounds which are soluble in the selective solvents. Selection of the appropriate solvents is the key to a successful biological guided extraction. In this study, solvents of different polarity were used to extract the root, stem and seed parts of C. cajan. The dichloromethane seed extract of C. cajan had the highest total phenolic content and dichloromethane was a solvent that provides the highest total phenolic content in comparison to those of methanol and water. Our result was correlated with the prior research work. Al-Saeedi and Hossain ${ }^{10}$ reported the following order of total phenolic obtained among the crude extracts of $C$. cajan seed was hexane $>$ chloroform $>$ methanol $>$ ethyl acetate $>$ butanol $>$ water. It was implied the non-polar organic solvent was more appropriate to extract phenolic compounds of C. cajan than polar solvent. Plant parts did not demonstrate the effect on the total phenolic content. The obtained results indicated that type of extraction solvent was an important factor on phenolic contents of C. cajan extracts.

The tyrosinase inhibitory activity study showed the methanol root extract have the greatest tyrosinase inhibitory capacity $\left(\mathrm{IC}_{50}=3.55 \mathrm{mg} / \mathrm{ml}\right)$. However, it was found that the standard kojic acid $\left(\mathrm{IC}_{50}=0.73 \mathrm{mg} / \mathrm{ml}\right)$ had potent activity than the most tyrosinase inhibitory extract from C. cajan approximately 5 folds. It had been reported that methanol seed extracts from C. cajan had more tyrosinase inhibitory activity than those of the ethanol extracts. ${ }^{11}$

Lin et al. ${ }^{12}$ investigated melanogenesis inhibition of Biochanin A from C. cajan. The results revealed that Biochanin A had melanogenesis inhibitory activity in vitro and in vivo with the similar inhibitory capacity to those of the standard arbutin without statistical difference. In the present study, it was found that root and stem extracts have a good tyrosinase inhibitory activity. This may due to the presence of Biochanin A in the root and stem of C. cajan.

It was reported that flavonoids including quercetin $\left(\mathrm{IC}_{50}=0.07 \mathrm{mM}\right)$, luteolin $\left(\mathrm{IC}_{50}=0.19 \mathrm{mM}\right)$ and kaempferol $\left(\mathrm{IC}_{50}=0.13 \mathrm{mM}\right)$ had a potent tyrosinase inhibitory activity which were similar to those of kojic acid $\left(\mathrm{IC}_{50}=0.014 \mathrm{mM}\right)$. Interestingly, flavonoid with the structure of $3-\mathrm{OH}$ and 4-carbonyl (3-hydroxy-4-keto moiety) in quercetin which had the similar structure to kojic acid, support a good tyrosinase inhibitory capacity. ${ }^{13}$ 
Table 1: Percentage yield of $C$. cajan extracts.

\begin{tabular}{cccc} 
& \multicolumn{3}{c}{ \%yield } \\
\cline { 2 - 4 } Plant parts & water & Dichloromethane & Methanol \\
\hline Stem & 5.186 & 1.324 & 1.79 \\
Root & 5.962 & 1.401 & 1.745 \\
Seed & 10.075 & 1.572 & 4.389 \\
\hline
\end{tabular}

Table 2: Total phenolic contents and tyrosinase inhibitory activities of C. cajan extracts.

\begin{tabular}{ccc}
\hline Extracts & $\begin{array}{c}\text { Total phenolic contents } \\
\text { (mg GAE/ g extracts) }\end{array}$ & $\begin{array}{c}\mathrm{IC}_{50} \text { of Tyrosinase } \\
\text { inhibition } \\
\text { ( } \mathrm{mg} / \mathrm{ml})\end{array}$ \\
\hline Root water & $5.95 \pm 0.997$ & $7.36 \pm 0.926$ \\
Root dichloromethane & $80.28 \pm 4.498$ & $4.62 \pm 0.455$ \\
Root methanol & $41.02 \pm 0.779$ & $3.55 \pm 0.346$ \\
Stem water & $9.16 \pm 0.698$ & $3.94 \pm 0.033$ \\
Stem dichloromethane & $72.46 \pm 4.099$ & $3.82 \pm 0.362$ \\
Stem methanol & $30.57 \pm 1.334$ & $12.43 \pm 0.679$ \\
Seed water & $4.27 \pm 0.918$ & $4.39 \pm 0.830$ \\
Seed dichloromethane & $92.00 \pm 1.243$ & $4.81 \pm 0.757$ \\
Seed methanol & $50.03 \pm 2.786$ & $7.48 \pm 0.655$ \\
Kojic acid (standard) & & $0.73 \pm 0.019$ \\
\hline
\end{tabular}

Values are expressed as mean \pm SD of triplicate measurements.

Phytochemical studies in C. cajan confirmed the presence of phenolic compound, flavonoids and stilbene i.e. cajanin, quercetin, genistein, biochanin A, betuinic acid and cajanol ${ }^{14-15}$ which may be related to the tyrosinase inhibitory capacity. Therefore, there should be further study on phytochemistry of this plant in more details.

\section{CONCLUSION}

The present study can be concluded that the extracts from different parts of C. cajan have different total phenolic contents. There should be further studies on the other biological activities of this plant such as anti-cancer and anti-microbial activities. Phenolic compounds are beneficial for health and disease prevention. The findings from the present study can be used as the alternatives for consumption of local vegetable for health promotion and further development as food supplementary products.

\section{ACKNOWLEDGEMENT}

This research was financially supported by Mahasarakham University, Thailand. The authors would like to thank the faculty of Science and the faculty of Pharmacy for facility support.

\section{CONFLICT OF INTEREST}

Authors declare no conflict of interest.

\section{ABBREVIATIONS}

GAE: Gallic acid equivalent; SD: Standard deviation; DMSO: Dimethyl sulfoxide

\section{REFERENCES}

1. Pal D, Mishra P, Sachan N, Ghosh, A. K. Biological activities and medicinal properties of Cajanus cajan (L) Millsp. Journal of Advanced Pharmaceutical Technology and Research. 2011;2(4):207.

2. Duker EG, Jaroszewski JW, Asomaning WA, Oppong BF, Christensen SB Antiplasmodial constituents of Cajanus cajan. Phytotherapy Research. 2004;18(2):128-30.

3. Zu YG, Fu YJ, Liu W, Hou CL, Kong Y. Simultaneous determination of four flavonoids in pigeonpea Cajanus cajan (L.) Millsp. leaves using RP-LC-DAD. Chromatographia. 2006;63(9-10):499-505.

4. Nahar L, Nasrin F, Zahan R, Haque A, Haque E, Mosaddik A. Comparative study of antidiabetic activity of Cajanus cajan and Tamarindus indica in alloxan-induced diabetic mice with a reference to in vitro antioxidant activity. Pharmacognosy Research. 2014;6(2):180-7.

5. Rani S, Poswal G, Yadav R, Deen MK. Screening of Pigeon pea (Cajanus cajan L.) Seeds for study of their flavonoids, total phenolic content and antioxidant properties. International Journal of Pharmaceutical Sciences Review and Research. 2014;28(2):90-4

6. Luo M, Liu X, Zu YG, Fu YJ, Zhang S, Yao LP, Efferth T. Cajanol, a novel anticancer agent from Pigeonpea Cajanus cajan (L.) Millsp. roots, induces apoptosis in human breast cancer cells through a ROS-mediated mitochondrial pathway. Chemico-Biological Interactions. 2010;188(1):151-60.

7. Kim YJ, Uyama H. Tyrosinase inhibitors from natural and synthetic sources: structure, inhibition mechanism and perspective for the future. Cellular and Molecular Life Sciences. 2005;62(15):1707-23.

8. Amin I, Norazaidah Y, Hainida KIE. Antioxidant activity and phenolic content of raw and blanched Amaranthus species. Food Chemistry. 2006;94(1):47-52

9. Alam N, Yoon KN, Lee TS. Evaluation of the antioxidant and antityrosinase activities of three extracts from Pleurotus nebrodensis fruiting bodies. African Journal of Biotechnology. 2011;10(11):2978-86.

10. Al-Saeedi $A H$, Hossain MA. Total phenols, total flavonoids contents and free radical scavenging activity of seeds crude extracts of pigeon pea traditionally used in Oman for the treatment of several chronic diseases. Asian Pacific Journal of Tropical Disease. 2015;5(4):316-321.

11. Rerk-am U, Kongsombat B, Tangsatirapakdee, Banchonglikitkul. Biological activity of Cajanus cajan ethanolic extracts. Thai Journal of Pharmaceutical Sciences. 2013;38(Suppl.):112-4.

12. Lin VC, Ding HY, Tsai PC, Wu JY, Lu YH, Chang TS. In vitro and in vivo melanogenesis inhibiton by Biochanin A from Trifolium pretense. Bioscience, Biotechnology and Biochemistry. 2011;75(5):914-8.

13. Kubo I, Kinst HI, Chaudhuri SK, Kubo Y, SaÂnchezb Y, Ogurab T. Flavonols from Heterotheca inuloides: Tyrosinase inhibitory activity and structural criteriay. Bioorganic and Medicinal Chemistry. 2000;8(7):1749-55.

14. Wink M. Evolution of secondary metabolites in legumes (Fabaceae). South African Journal of Botany. 2013;89:164-75.

15. Nix A, Paull CA, Colgrave M. The flavonoid profile of pigeonpea, Cajanus cajan: a review. SpringerPlus. 2015;4(1):125.

Cite this article: Maneechai S, Rinthong P. Total Phenolic Content and Tyrosinase Inhibitory Potential of Extracts from Cajanus cajan (L.) Millsp.. Pharmacog J. 2018;10(6)Suppl:s109-s112. 
GRAPHICAL ABSTRACT

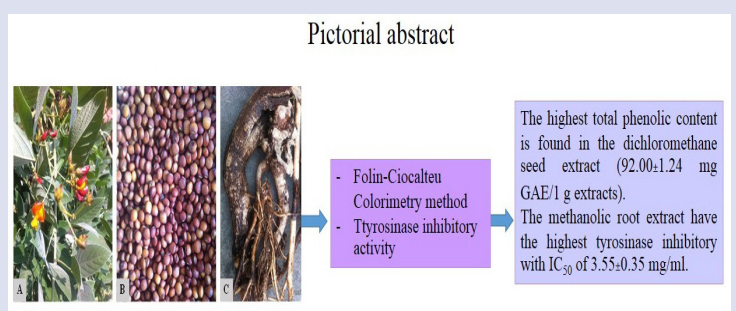

Cajanus cajan (L.) Millsp.

A: Flower, leave and stem; B: seed; C: root

root, stem and seed

(dichloromethane, water,

methanol)

\section{SUMMARY}

- The seed extracts from Cajanus cajan (L.) Millsp. have the highest total phenolic content and tyrosinase inhibitory activity in comparison to those of stem and root extracts.

- The dichloromethane seed extract have the highest total phenolic content followed by those of methanol and water extracts.

- Type of extraction solvent was an important factor on phenolic contents of $C$. cajan extracts.

- Tyrosinase inhibitory activity study revealed that methanolic root extract have the highest tyrosinase inhibitory activity with the lowest $I C_{50}$ value in comparison to those of other extracts.

\section{ABOUT AUTHORS}

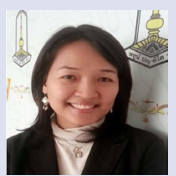

Suthira Maneechai: Ph.D. in Pharmacognosy, Faculty of Pharmaceutical Science, Chulalongkorn University, Thailand. Currently, she is the lecturer at Division of Biology, Department of Science, Faculty of Science, Mahasarakham University, Thailand. She has experiences in the area of Biology working mainly in plant biological activity and ethnobotany. 